\title{
Substitution of natural feed with artificial feed on the survival and growth rate of giant-snakehead Channa micropeltes
}

\section{Substitusi pakan alami dengan pakan buatan terhadap tingkat kelangsungan hidup dan laju pertumbuhan ikan toman Channa micropeltes}

\author{
Sarmila $^{1^{*}}$, Susilawati ${ }^{1}$, Sri Warastuti $^{1}$ \\ ${ }^{1}$ Study Program of Marine Sciences and Fisheries, State Polytechnic of Pontianak \\ Pontianak, West Kalimantan, Indonesia \\ *Corresponding author: sar36_koe@yahoo.co.id
}

(Received December 16, 2018; Accepted February 3, 2019)

\begin{abstract}
The purpose of this study was to determine the best percentage of artificial feed substitution for growth and survival rate of giant-snakehead. This study used a completely randomized design (CRD) with 4 levels of artificial feed substitution dose treatment, namely $25 \%, 50 \%, 75 \%, 100 \%$, and control (without artificial substitution). The feed used in the form of fresh trash fish mixed with artificial feed FF-999 with a protein content of 35\%. The results showed that the control treatment (100\% trash fish) gave the best survival rate and spesific growth rate of $75 \%$ and $2.12 \% /$ day, respectively. Meanwhile, the percentage of artificial feed substitution treatment which gave the best survival rate and specific growth rate was found in the substitution percentage treatment of $25 \%$ artificial feed with a survival rate of $66.67 \%$ and a daily weight growth rate of $1.89 \%$ /day. Substitution of $100 \%$ artificial feed caused death with a $0 \%$ survival rate.
\end{abstract}

Keywords: artificial feed, feed substitution, giant-snakehead, survival rate, growth

\begin{abstract}
ABSTRAK
Penelitian ini bertujuan menentukan persentase substitusi pakan buatan yang terbaik untuk laju pertumbuhan, dan tingkat kelangsungan hidup ikan toman. Penelitian ini menggunakan rancangan acak lengkap (RAL) dengan perlakuan 4 level dosis substitusi pakan buatan yaitu 25\%, 50\%, 75\% dan 100\% serta 1 kontrol (tanpa substitusi pakan buatan). Pakan yang digunakan berupa ikan rucah segar dicampur dengan pakan buatan berupa pellet dengan merk FF-999 berkadar protein 35\%. Hasil penelitian menunjukkan bahwa perlakuan kontrol (100\% ikan rucah) memberikan tingkat kelangsungan hidup dan laju pertumbuhan berat harian terbaik masing-masing sebesar $75 \%$ dan $2.12 \%$ /hari. Sementara untuk perlakuan persentase substitusi pakan buatan yang memberikan tingkat kelangsungan hidup dan laju pertumbuhan terbaik terdapat pada perlakuan persentase substitusi sebesar $25 \%$ pakan buatan dengan tingkat kelangsungan hidup $66.67 \%$ dan laju pertumbuhan berat harian $1.89 \%$ /hari. Substitusi 100\% pakan buatan menyebabkan kematian dengan tingkat kelangsungan hidup 0\%.
\end{abstract}

Kata kunci: ikan toman, kelangsungan hidup, laju pertumbuhan, pakan buatan, substitusi pakan. 


\section{INTRODUCTION}

Giant snakehead Channa micropeltes is one of the local species in Kalimantan, especially West Kalimantan. It is consumed mainly by the locals due to its flavour and affordable price. Sarmila et al. (2016) noted that in March 2016, the price of the captured giant snakehead in fish landing station and Kapuas Hulu Lake reached IDR $30.000 / \mathrm{kg}$. Meanwhile, it was around IDR $50.000-60.000 / \mathrm{kg}$ in the market or downtown. Giant snakehead is known for its abundant protein and albumin content, even compared to striped snakehead Channa striata. Albumin is beneficial in wound recovery and as nutrition sources, especiallt for kids. Suwandi et al. (2014) reported that the highest protein content of a female striped snakehead was $20.14 \% / \mathrm{kg}$. In addition, Pratama et al. (2014) found that a 35-300 g of giant snakehead had $16.8 \%$ of protein. According to Fitriyani et al. (2020), it was stated that giant snakehead contained higher albumin content $(3.6147 \mathrm{~g} / \mathrm{dL})$ compared to the striped snakehead $(3.3076 \mathrm{~g} / \mathrm{dL})$. Surely, giant snakehead will be the first on list of albumin and protein source.

Giant snakehead became a prospective local species to be cultured (Nugroho et al., 2012). However, various challenges of giant snakehead culture were frequently met. Feed is one of the main problems in giant snakehead culture (Ansyari $\&$ Slamat, 2020). The grow out phase of giant snakehead is currently occurring in floating cage in the river and lake. It was done to get the small fish as feed easily. Ansyari and Slamat (2020) learned the feed source characteristic in Monoton swamp, Panggang Lake, South Kalimantan and identified that Rasbora sp., Barbs, Anabas testudineus, Mystus sp., Trichopodus sp., and Helostoma temminckii dominated the territory. Small fish caught was mostly done by the farmers to reduce commercial feed costs. It also suits the eating habit of giant snakehead which is predator.

This particular habit was considered as notenvironment friendly due to the small fish usage as feed. It was concerned because it potentially threated the population of some certain species and disrupted the diversity in that area. Muchlisin et al. (2013) and Aokit and Nalle (2018) clearly stated that excessive exploration will threat the natural resources. It is undoubtedly the complete opposite of the conservation aquaculture concept. Furthermore, the giant snakehead grow out which only lay on the catched feed could not be developed in a larger scale due to the limitation of feed supply, both quality and quantity, and the area as well. A scientific information about commercial feed for gaint snakehad has not been available yet. Therefore, commercial feed is needed to be adapted to giant snakehead culture to support a sustainable aquaculture. Due to this reason, this study was held to evaluate the feed substitution for giant snakehead to gain the best survival and growth rate.

\section{MATERIALS AND METHODS}

This study was conducted for 45 days. Fifteen units of fiber plastic tub equipped with pump, cover net, and filter were used in this study. Those tubs sized in $60.5 \mathrm{~cm} \times 41.5 \mathrm{~cm} \times 34.5 \mathrm{~cm}$ and filled with $50 \mathrm{~L}$ of water. Pump was used to flow the water and supply oxygen. Cover net was put to prevent fish jumping outside the tub. The filter consisted of cottons which filtered dirt and unwanted suspension in the water. All tubs were randomly arranged.

The giant snakehead seeds were catched in nature from Kapuas River and Kapuas Hulu region. Those seeds were selected to gather similar size, healthy, no wound, and no disability. Initially, the seeds were adapted in a pound for one week. It was conducted to certain that all seeds were in good condition. Initial biomass was weighed and the tested seeds were reared in the next day. The stcoking density was 20 individuals/tub. A complete randomized design was applied in this study. Four treatments and one control were implemented and each treatment had three replications. The dosage of commercial feed and trash fish was modified based on Fauzi et al. (2008) and Prihadi (2011). The mentioned treatment was described below:

Treatment A: $25 \%$ of commercial feed $+75 \%$ of trash fish

Treatment B: $50 \%$ of commercial feed $+50 \%$ of trash fish

Treatment C: $75 \%$ of commercial feed $+25 \%$ of trash fish

Treatment D: $100 \%$ of commercial feed

Control: $100 \%$ of trash fish

Body weight sampling was managed every 15 days. The commercial feed used in this study was floating feed FF-999 with 35\% of crude protein content, $2 \%$ of crude fat, $3 \%$ of crude, $13 \%$ of crude ash, and $12 \%$ of water content. Feeding was conducted based on the prescribed treatment. It 
was delivered three times a day using at satiation method. Commercial feed and trash fish were mixed based on each treatment and grinded. The tested feed was delivered in a paste form. The tested parameters were average weight, survival rate, and specific growth rate.

\section{Survival rate}

The survival rate was calculated by comparing the current and initial population. It was sampled in the beginning and the end of the study. A formulation by Djajasewaka (1985) was applied to calculated survival.

$$
\mathrm{SR}(\%)=\frac{\mathrm{Nt}}{\mathrm{No}} \times 100
$$

Note :

$\mathrm{SR}=$ Survival rate $(\%)$

$\mathrm{Nt} \quad=$ final population (individuals)

No $\quad=$ initial population (individuals)

\section{Specific growth rate (SGR)}

Weight data was collected in the morning to avoid stress caused by temperature changes. The sampling was done in the initial and the end of the study. SGR was calculated using this following formula by Huisman (1976) and Sutiana et al. (2017):

$$
\operatorname{SGR}(\% / \text { day })=\left[\sqrt[t]{\frac{\mathrm{Wt}}{\mathrm{Wo}}}-1\right] \times 100
$$

Note :

$$
\begin{array}{ll}
\mathrm{SGR} & =\text { Specific growth rate }(\% / \text { day }) \\
\mathrm{t} & =\text { rearing period }(\text { day }) \\
\mathrm{Wt} & =\text { Final weight }(\mathrm{g}) \\
\mathrm{Wo} & =\text { Initial weight }(\mathrm{g})
\end{array}
$$

\section{Data analysis}

Growth and survival were analyzed statistically. Normality test was done first. Analysis of variance in IBM SPSS Statistics 25 was applied to test the hypothesis with $95 \%$ of confidence level. Tukey test was used as well for further analysis.

\section{RESULTS AND DISCUSSION}

\section{Results}

Survival rate of giant snakehead was shown in Figure 1. The most excellent survival was observed in treatment $\mathrm{A}(66.67 \%)$, followed by treatment B (55\%), C (53.33\%), and D (0\%), respectively. However, it was still lower than the survival rate in control (75\%). Statistical analysis explained that the survival rate amongst treatments was differ significantly. Tukey's analysis presented that there was a significant difference amongst treatment $\mathrm{A}$ and $\mathrm{B}, \mathrm{A}$ and $\mathrm{C}, \mathrm{A}$ and $\mathrm{D}, \mathrm{B}$ and $\mathrm{D}, \mathrm{B}$ and control, $\mathrm{C}$ and $\mathrm{D}$, and $\mathrm{C}$ and control. Besides survival rate, the body weight data was also collected. The initial average weight was $6.20 \mathrm{~g}$ /individual. The final average weight after 45 days of rearing was presented in Table 1.

The greatest growth was shown by treatment A $(1.89 \pm 0.06 \% /$ day $)$. Treatment B $(1.71 \pm 0.03$ $\% /$ day $)$ and $\mathrm{C}(1.23 \pm 0.11 \% /$ day $)$ followed, respectively. Post hoc test also showed that there was a significant difference amongst treatment $(\mathrm{P}<0.05)$. Precisely, Figure 2 showed the specific growth rate below.

\section{Discussion}

Generally, the survival rate of giant snakehead during the study differed significantly. Treatment A and control presented $66.6 \%$ and $75 \%$ of survival, respectively. On the contrary, treatment D showed the lowest survival $(0 \%)$. It was assumed due to the inability to adapt towards the full commercial feed treatment. Haryanto et al. (2014) stated that the exposure of extreme different diet would affect its nutrition intake. The lack of nutrition intake impacted fish self defense towards disease or distressing environmental condition. Furthermore, it obviously lowered the survival rate and biomass production (Simanjuntak et al., 2017; Bagayo et al., 2019). Moreover, it might lead to mortality.

Growth and survival rate have always been the major aspect to determine the triumph of aquaculture. In this study, the specific growth rate

Table 1. Average body weight of giant snakehead (g/individual)

\begin{tabular}{cccccc}
\hline \multirow{2}{*}{ Day- } & \multicolumn{5}{c}{ Treatment } \\
\cline { 2 - 6 } & $\mathrm{A}$ & $\mathrm{B}$ & $\mathrm{C}$ & $\mathrm{D}$ & $\mathrm{K}$ \\
\hline 0 & $6.20 \pm 0.00$ & $6.20 \pm 0.00$ & $6.20 \pm 0.00$ & $6.20 \pm 0.00$ & $6.20 \pm 0.00$ \\
15 & $7.07 \pm 0.12$ & $6.73 \pm 0.15$ & $6.29 \pm 0.09$ & $6.07 \pm 0.15$ & $7.43 \pm 0.15$ \\
30 & $8.92 \pm 0.24$ & $7.45 \pm 0.28$ & $6.46 \pm 0.29$ & $5.00 \pm 0.00$ & $9.56 \pm 0.10$ \\
45 & $14.42 \pm 0.36$ & $13.29 \pm 0.19$ & $10.78 \pm 0.52$ & - & $15.91 \pm 0.41$ \\
\hline
\end{tabular}


was significantly differed amongst treatments. The control treatment showed $2.12 \%$ /day of growth while treatment A resulted $1.89 \%$ /day of specific growth rate. Treatment $\mathrm{C}$ had the lowest growth of all treatments $(1.23 \% /$ day $)$. A living creature is said to experience growth when body length, weight, and volume were occurred in a certain period of time (Kusumaningrum et al., 2014). This study also explained that giant snakehead was not fully depended on trash fish, yet adaptable to commercial feed. The ratio between trash fish and commercial feed was arranged gradually. As mentioned before, treatment $\mathrm{C}$ had the lowest growth. It was presumably caused by inability to fully adapt to the commercial feed. Furthermore, treatment D that applied fully commercial feed did not exhibit any certain interest to the feed although they had been fasted for one week. Solovyev et al. (2014) and Pratama et al. (2020) stated that giant snakehead was categorized as carnivorous species that prey fish juvenile, worm, frog, prawn, and crabs. Ansyari and Slamat (2020) explained that giant snakehead had $79.15 \%$ of small fish, $7.2 \%$ of mollusc, $1.45 \%$ of crustaceans, waste, and unidentified metabolized compounds in their guts. It confirmed that giant snakehead is carnivorous. It also explained that the tested fish in treatment $\mathrm{D}$ did not experience any weight gain.

Ndome et al. (2011) stated that the amount of feed consumed by a fish will directly affect its growth. Weight loss experienced by treatment $\mathrm{D}$ was generated by nutrition lacks. The tested fish in treatment D consumed the commercial feed in a low amount. The energy stored in their body was utilized in body maintenance and basal metabolism continuously (Lubis et al., 2019; Schrama et al., 2018). It led to weight loss and even mortality. Growth could be expressed physically and energetically. Physically, growth was observed

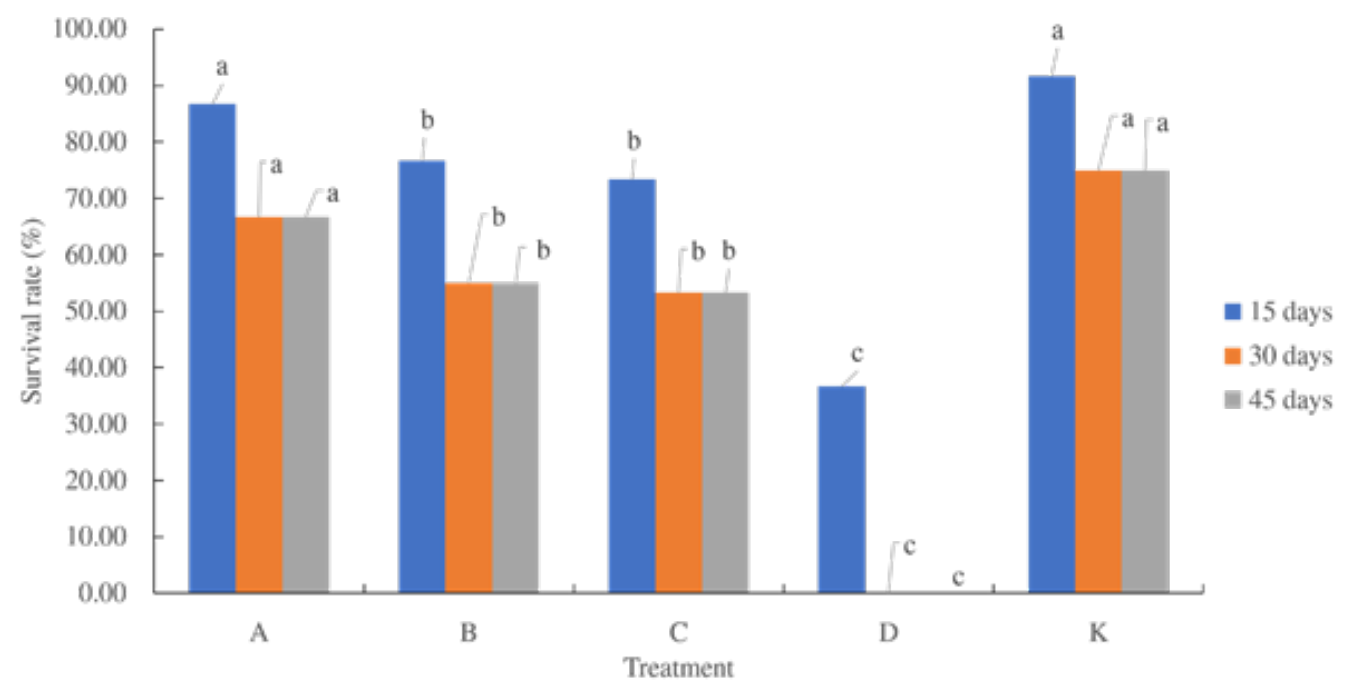

Figure 1. Survival rate of giant snakehead after 45 days of rearing.

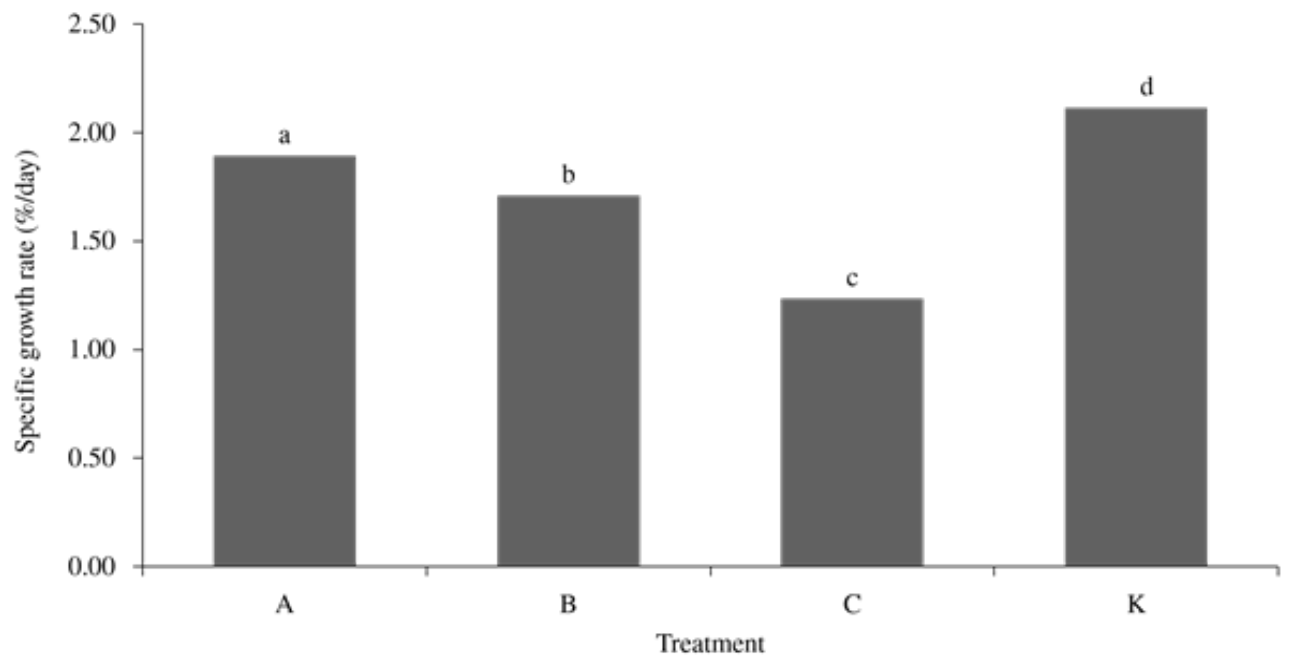

Gambar 2. Specific growth rate of giant snakehead after 45 days of rearing. 
in a certain period of time based on the body changes. Meanwhile, energetically, was signed with total energy changes in a certain period of time. Growth would be occurred when the energy for basal metabolism, digestion, daily activity were fulfilled (Halver, 2002). Nevertheless, the other substitution treatment showed some sort of interest to consume commercial feed mixed with the trash fish in a form of paste. This study was more focused on body weight of giant snakehead because it often retails based on its weight. Fish growth is frequently affected by density (Faisyal et al., 2016), environment, and feed management (Yanuar, 2017). In addition, physiology, feed supply (quantitative and qualitative), water quality parameter also contributed in fish growth. The captured seed of giant snakehead required a relatively long time to adapt in a cultured environment.

The significant growth difference amongst treatments was also presumably caused by the smell of commercial feed which was not as fishy as the trash fish so that it did not induce the appetite. The smell of a feed was also involved in their response towards feed. The giant snakehead could not directly responded to the commercial feed. It was the reason why they were fasted before hand for one week. Arditya (2019) mentioned that striped snakehead fastly responded to a certain feed that smells strongly so that it fastened the duration of feed soaked in the water. Taste, smell, and form are essential to ease the fish in detecting feed (Subandiyono \& Hastuti, 2016). Triyanto et al. (2020) explained the existence of olfactory receptor facilitated to detect chemical compound released by the feed. In addition, taste buds also help to determine whether the feed is edible or not. Generally, eating activity was started with the appetite and responses towards certain stimulus, eating, satiated, and lower appetite (Subandiyono \& Hastuti, 2016). Appetite lost affected the nutrition supply consumed by fish so that they would lack of nutrition utilized to grow.

Carnivorous fish is aggressive, especially with empty stomach so hopefully they will straightly consume the commercial feed. Arditya et al. (2019) conditioned a certain species of fish in a hunger so that they were more responsive towards the commercial feed. Unfortunately, the capacity of giant snakehead eating commercial feed is considerably low. It was assumed cause by its eating habit it nature to prey smaller fish. Fish eating habit is related to several factors, i.e. type, quantity, and quality (Ansyari \& Slamat,
2020). Therefore, the experimental feed was firstly processed by mixing the commercial and trash fish thoroughly so it was easier for the fish to consume the experimental feed. Precisely, the tested feed was in a paste form because it was suitable for fish seed.

The commercial feed had $35 \%$ of protein, $2 \%$ of crude fiber, $3 \%$ of ash, and $12 \%$ of water. The protein content was decent and it was combined with fresh trash fish to enhance its taste. According to Yulisman et al. (2012) showed that the protein requirement for striped snakehad Channa striata to support its growth ranged from $35 \%-40 \%$. Hidayat et al. (2013) also added that protein had essential roles in tissues forming, growth, and fixing damaged tissues. Moreover, Subandiyono and Hastuti (2016) stated that protein was also required to enhance body defense and protein was also relatively costly in feed industry because it could reach up to $30-55 \%$ in fish formulation. Natural feed substitution with commercial feed was the beginning of giant snakehad adaptation in a culture environment. Giant snakehead culture will be more successful when a suitable commercial feed is found or made in the future.

\section{CONCLUSION}

The feed substitution of $25 \%$ had the best growth (1.89\%/day) and survival (66\%) amongst treatments. The giant snakehead has not been able to consume commercial feed fully yet.

\section{REFERENCES}

Ansyari P, Slamat. 2020. Food characteristics of Indonesian snakehead in Danau Panggang Monotonous Swamp, South Kalimantan. Warta Iktiologi 4: 27-33.

Akoit MA, Nalle MN. 2018. Pengelolaan sumberdaya perikanan berkelanjutan di Kabupaten Timor Tengah Utara berbasis pendekatan bioekonomi. Jurnal Agribisnis Indonesia 6: 85-108.

Arditya BP, Subandiyono, Samidjan I. 2019. The effects of various sources of dietary attractant on the feed response, total feed consumption, and growth of snakehead fingerlings Channa striata. Jurnal Sains Akuakultur Tropis 3: 70-81.

Bagayo HE, Jurnardi, Setyawati TR. 2019. Pertumbuhan dan sintasan ikan nila Oreochromis niloticus yang diberi konsumsi pakan buatan tepung cacing tanah Pheretima 
sp. dan alga coklat Sargassum spp.. Jurnal Protobiont 8: 32-38.

Djajasewaka H. 1985. Pakan Ikan. CV Yasaguna, Jakarta. 45 hal.

Faisyal Y, Rejeki S, Widowati LL. 2016. Effect stocking density on the growth and survival rate milkfish Chanos chanos in floating net cages in water abraded village Kaliwlingi district Brebes. Journal of Aquaculture Management and Technology 5: 155-161.

Fauzi I, Mokoginta, D Yaniharto. 2008. Rearing of humpback grouper Cromileptes altivelis fed on pellet and trash fish in cage culture system. Jurnal Akuakultur Indonesia 7: 65-70.

Fitriyani E, Nuraenah N, Deviarni IM. 2020. Perbandingan komposisi kimia, asam lemak, asam amino ikan toman Channa micropeltes dan ikan gabus Channa striata dari perairan Kalimantan Barat. Manfish Journal 1: 71-82.

Halver JE, RW Hardy. 2002. Fish Nutrition Third Edition. Academic Press an Elsevier Science Imprint, 839 p.

Haryanto P, Pinandoyo, Ariyati RW. 2014. The influence of different feeding dose on growth of juvenil tiger grouper Epinephelus fuscoguttatus. Journal of Aquaculture Management and Technology 3: 58-66.

Hidayat D, AD Sasanti, Yulisman. 2013. Survival rate, growth and feed efficiency of snake head Channa striata was feed by golden apple snail Pomaecea sp.. flour. Jurnal Akuakultur Rawa Indonesia 1: 161-172.

Huisman EA. 1976. Food convertion efficiencies at maintenance and production levels for carp Cyprinus carpio Linn. and rainbow trout Salmo gairdneri Rich. Aquaculture 9: 159-273.

Kusumaningrum GA, Alamsyah MA, Masithah ED. 2014. Albumin level test and snakehead fish Channa striata growth with different commercial feed protein level. Jurnal Ilmiah Perikanan dan Ilmu Kelautan 6: 25-29.

Lubis RA, Alimuddin, Utomo NBP. 2019. Enrichment of recombinant growth hormone in diet containing different levels of protein enhanced growth and meat quality of striped catfish Pangasionodon hypophthalmus. BIOTROPIA 26: 1-8.

Muchlisin ZA, Thomy Z, Fadli N, Sarong MA, Siti-Azizah MN. 2013. DNA barcoding of freshwater fishes from Lake Laut Tawar, Aceh Province, Indonesia. Acta Ichthyologica et Piscatoria 43: 21-29.

Ndome CB AO Ekwu, AA Ateb. 2011. Effect of feeding frequency on feed consumption, growth and feed conversion of Clarias gariepinus $\times$ heterobanchus longifilis hybrid. American-Eurasian Journal of Scientific Research 6: 06-12.

Nugroho E, Sukadi MF, Huwoyon GH. 2012. Beberapa jenis ikan lokal yang potensial untuk budidaya: Domestika, teknologi pembenihan, dan pengelolaan kesehatan lingkungan budidaya. Jurnal Media Akuakultur 7: 52-57.

Pratama WW, Nursyam H, Hariati AM, Hutagalung RA. 2014. Komposisi proksimat, aktivitas enzim protease dan lipase ikan toman Channa micropeltes ukuran yang berbeda asal Kalimantan Barat. Manfish Journal 2: 1-7.

Pratama WW, Nursyam H, Hariati AM, Islamy RA, Hasan V. 2020. Short Communication: Proximate analysis, amino acid profile and albumin concentration of various weights of giant snakehead Channa micropeltes from Kapuas Hulu, West Kalimantan, Indonesia. Biodiversitas 21: 1196-1200.

Prihadi DJ. 2011. Pengaruh jenis dan waktu pemberian pakan terhadap tingkat kelangsungan hidup dan pertumbuhan kerapu macan Epinephelus fuscoguttatus dalam karamba jaring apung di Balai Budidaya Laut Lampung. Jurnal Akuatika 2: 1-11.

Sarmila, Shilman MI, Susilawati, Sukiman, Wahyu WP. 2016. Identifikasi keragaman jenis ikan lokal di Danau Selogan Kecamatan Jongkong Kabupaten Kapuas Hulu. Laporan Penelitian Terapan, Politeknik Negeri Pontianak.

Schrama JW, Haidar MN, Geurden I, Heinsbroek LTN, Kaushik SJ. 2018. Energy efficiency of digestible protein, fat and carbohydrate utilisation for growth in rainbow trout and Nile tilapia. British Journal of Nutrition 119: 782-791.

Simanjuntak M, Siregar R, Wanna C. 2017. Studi beberapa jenis pakan terhadap pertumbuhan dan sintasan ikan nila Oreochromis niloticus. Samudra Akuatika 1: 11-15.

Solovyev MM, Kashinskaya EN, Izvekova GI, Gisbert E, Glupov VV. 2014. Feeding habits and ontogenic changes in digestive enzymes patterns in five freshwater teleosts. Journal of Fish Biology 85: 1395-1412.

Subandiyono, Hastuti S. 2016. Buku Ajar Nutrisi Ikan. Lembaga Pengembangan dan Penjaminan Mutu Pendidikan Universitas Diponegoro, Semarang.

Sutiana, Erlangga, Zulfikar. 2017. The effect of rGH and thyroxine hormone dosage in feed on the growth and survival rate of koi larvae Cyprinus carpio L. Acta Aquatica 4: 76-82. 
Suwandi R, Nurjanah, Margaretha W. 2014. Body parts proportion and proximate levels of snakehead on various sizes. Jurnal Pengolahan dan bioteknologi Hasil Perikanan 17: 22-28.

Triyanto, Tarsim, Utomo DSC. 2020. Influences of lamp irradiation exposure on growth and survival of juvenile sneakhead fish Channa striata (Bloch, 1793). e-Jurnal Rekayasa dan Teknologi Budidaya Perairan 8: 1029-1038.
Yanuar V. 2017. Effect of different types of feed on growth rate of tilapia fish Oreochiomis niloticus and water quality in the aquarium maintenance. Ziraa'ah 42: 91-99.

Yulisman, Fitrani M, Jubaedah D. 2012. Peningkatan pertumbuhan dan efisiensi pakan Ikan gabus Channa sriata melalui optimasi kandungan protein dalam pakan. Berkala Perikanan Terubuk 40: 47-55. 